DOI: $10.17805 /$ zpu.2015.3.25

\title{
О происхождении русского народа и русского языка: Тредиаковский, Ломоносов, Сумароков
}

\author{
A. В. РАСТЯГАЕВ \\ ( САМАРСКИЙ ФИЛИАЛ МОСКОВСКОГО ГОРОДСКОГО ПЕДАГОГИЧЕСКОГО УНИВЕРСИТЕТА), \\ Ю. В. СЛОЖЕНИКИНА \\ (САМАРСКИЙ ГОСУДАРСТВЕННЫЙ ТЕХНИЧЕСКИЙ УНИВЕРСИТЕТ)
}

В статье анализируются истоки полемики о происхождении русского народа и русского языка, начатой в первой трети XVIII в. В предпринятом исследовании устанавливаются идеологические параллели между трудом В. К. Тредиаковского «Три рассуждения о трех главнейших древностях российских...» (1757); первым томом «Древней Российской истории» М. В. Ломоносова (1758); статьей А. П. Сумарокова «О коренных словах русского языка», опубликованной в «Трудолюбивой пчеле» (1759).

Тредиаковский относит образование словенского (по терминологии автора) языка в глубь времен. По его мнению, язык скифов, которых он считает предками русских, был славянским по происхождению. Первоначальный язык следует именовать словенским от «слова», а предка его - славенским - от «славы», приобретенной сильным, могучим народом. Построенная Тредиаковским хронология, предполагающая, с одной стороны, чистоту русского языка, идущую от первоначальных неиспорченных времен, с другой древность и могущество, должна быть полезнее всего российскому народу.

Для Ломоносова была важна политическая составляющая русской науки и словесности. Ломоносов также утверждал идею древности славян. Однако он не считал скифов предками россиян, а напротив, указывал, на победы славян над скифами. Ему было близко происхождение самоназвания славянского племени от славных его деяний. Ломоносов считал варяг потомками роксолан - славенского народа, жившего в междуречье Днепра и Дона и говорившего на славенском языке. В именах князей, пришедших от варягов, он видит русские корни. Ломоносов утверждает, что множество племен говорило на славенском языке еще до рождества Христова. Ломоносов убежден, что славенский язык ни от греческого, ни от латинского не происходит, но на синхронном срезе существует рядом с ними, как равный.

Как и Тредиаковский, Сумароков называл скифский язык предком российского языка, подчеркивая боевую славу кочевых племен. Сумароков прибегает к многочисленным этимологическим сравнениям. Чутьем писателя он улавливает именно те тематические группы, которые впоследствии составили основу современных сравнительно-исторических изысканий.

Являясь оппонентами в более частных вопросах, все три автора середины XVIII в. были убеждены в единстве научной и политической составляющей русской истории и русского языка. Изменившийся к середине XVIII в. вектор научных и публицистических изысканий стал реакцией на Петровские реформы, которые привели к специфическому культурному изоляционизму «новой» российской нации.

Ключевые слова: XVIII в., происхождение русского языка, М. В. Ломоносов, В. К. Тредиаковский, А. П. Сумароков.

\section{ВВЕАЕНИЕ}

C культурно-исторической точки зрения в петровской России декларировался разрыв с прежней патриархальной традицией, ориентированной на канонический тип культуры. Теоцентрический уклад жизни был заменен светским этикетом, в качестве вектора развития было избрано западное направление, сакральную роль патриарха взял на себя монарх, душеполезная церковная литература активно замещалась художественной, научной, публицистической, была проведена реформа графики, 
а язык стал избавляться от устаревших церковнославянизмов и пополняться словами из европейских языков. По мысли М. Н. Виролайнен, «...еее большее значение имело то конфликтное взаимодействие, в которое эти новшества повсеместно вступали со старой русской реальностью, с естественным языком старой русской культуры» (Виролайнен, 2007: 219).

Однако такое положение дел - оторванность от предшествующего исторического развития - просуществовало недолго. Уже с 1730-х годов в сочинениях Байера, Миллера, Татищева начинает подниматься вопрос о происхождении российского народа, самих наименований Русь и Россия. К середине XVIII столетия к полемике подключились Тредиаковский, Цомоносов, Сумароков. И эта проблема, считает Е. А. Погосян, выходила за рамки собственно научной и становилась «фактом официальной культуры» (Погосян, 1999: 8).

О том, что споры зачастую не исчерпывались только научной дискуссией, свидетельствуют воспоминания Аомоносова. В «Краткой истории о поведении Академической канцелярии» он писал: «Миллер требовал, чтобы диссертацию его [ «Происхождение имени и народа российского». - A. P., Ю. С.] рассмотреть всем Академическим собранием, что и приказано от президента. Сии собрания продолжались больше года. Каких же не было шумов, браней и почти драк! Миллер заелся со всеми профессорами, многих ругал и бесчестил словесно и письменно, на иных замахивался в собрании палкою и бил ею по столу конференцскому. И наконец у президента в доме поступил весьма грубо, а пуще всего асессора Теплова в глаза бесчестил. После сего вскоре следственные профессорские собрания кончились, и Миллер штрафован понижением чина в адъюнкты» (цит. по: Свирская, 1952: 549).

Попытаемся установить параллели между исследованием В. К. Тредиаковского «Три рассуждения о трех главнейших древностях российских, а именно: I. О первенстве словенского языка перед тевтоническим. II. О первоначалии россов. III. О варягах руссах словенского звания, рода и языка» (1757); первым томом «Аревней Российской истории» М. В. Аомоносова (1758); статьей А. П. Сумарокова «О коренных словах русского языка», опубликованной в «Трудолюбивой пчеле» (1759).

\section{ПРОИСХОЖАЕНИЕ ЯЗЫКА КАК КОСМОГОНИЯ: ТРЕАИАКОВСКИЙ}

Тредиаковский отодвигает происхождение словенского языка и россов в глубь времен. «Три рассуждения о трех главнейших древностях российских...» были написаны им в 1757 г., но опубликованы уже после смерти автора в 1773 г. В рассуждении первом «О первенстве словенского языка перед тевтоническим» Тредиаковский утверждает: «...у Потомковъ отъ сыновъ Іафетөовыхъ, то есть у Скитөовъ и Целтовъ, по смбшаніи языковъ, первенствующій языкъ былъ единъ и общій, именножъ Скитөскій, которому точно надлежало быть, Словенскому отъ слова, и который въ посльдующія времена по различію мбстъ, прехожденій, смбтеній, и раздбленій, отъ единаго своего кореня, многими сродственными и сходственными разрасся древесами, и столькими сихъ древесъ вђтьвьми и отрасльми раскинулся, сколько слышится нынђ языковъ во всбхъ западныхъ и сбверныхъ земляхъ, а отъ части и въ восточныхъ» (Тредиаковский, 1849: 332). Скифский язык, считает автор, был славянского происхождения, а само название скифь (скитфь) происходит «отъ СКИТАНІЯ, то есть отъ свободнаго прехожденія съ мбста на мбсто» (Тредиаковский, 1849: 341-342; прописные и курсив здесь и далее в цитатах даны по источникам. - A. Р., Ю. С.)1. 
Аля Тредиаковского проблема происхождения языка носила космогонический характер. В своем «мифе творения» он ссылается на некие халдейские и персидские первоисточники: «Означается первенство, или по крайней мбрб, преглубокая древность Словенскаго языка Халдейскимъ мнБніемъ о Космогоніи или свБторожденіи, предложеннымъ во Всемірной Істории съ Английскія въ томъ первомъ, на страницб двадцать четвертой введенія. Предлагается тамъ, что съ начала міръ былъ токмо ОМОРОКА. Но слово сіе точно есть Словенское, значащее Морокъ или Мракъ, бывшій вкругъ: повсюду. Сіежъ самое означается и мнбніемъ мудрецовъ Персидскихъ, приведеннымъ тамже на страницб семдесятъ третіей въ примбъаніи» (там же: 337-338). Поэтому для Тредиаковского определение «ветвей и отраслей» языкового древа есть установление мирового порядка.

Аля Тредиаковского важно выявить преемственность развития, определить, какой исторический путь прошел словено-российский язык, к которому автор подлинно горит «пламеннымъ сердолюбіемъ» (там же: 338). Аля обозначения современного писателю языка он использует вслед за почитаемыми им авторами «Всемирной истории» 2 термин «московитский язык». Эти ученые и благорассудительные люди также считают скифский язык начальным и повествуют: «Обширное пространство земель ихъ (Скитөскихъ), и частыи случаи приключавшіися имъ (Скитөамъ) к смбшенію съ другими народами, долженствовали естественно ввесть въ ихъ языкъ разныи діалекты, кои могли преизрядно произвесть языки Московитскій, Славенскій, Польскій, Аатскій, Шведскій, Саксонскій, и другихъ многихъ народовъ, между которыми ясно усматривается довольное сходство, подаюшчее причину къ закдюченію, что всь сіи языки имбютъ одно и тожъ начало» (там же: 336 ).

Аля доказательства родства языков Тредиаковский считает вполне возможным анализ имен. Вслед за Генселием он утверждает, что «неложный знакъ есть древности во всякомъ языкь» (там же: 339). Такими неложными древностями для писателя являются коренные слова родного языка. Филолог, однако, осторожен, он вполне осознает возможность звуковых совпадений и понимает, что должны быть законы, по которым следует производить сопоставление языков. Он пишет: «Знаю, что произведеніе именъ есть такой доводъ, которой опасно и благоразумно приводить должно: ибо оно сходственнымъ звономъ, въ самомъ чуждомъ языкъ изобрбтаемомъ, способно и прельстить и обольстить можетъ. Но ежели такое произведеніе законамъ своимъ правильно слђдуетъ; то едваль сего доказательства, въ семъ случаб, возможетъ быть другое въроятнђе» (там же: 338-339).

Иатинский язык Тредиаковский считает «растленным», а вот с греческим видит множество совпадений, причем грамматического характера: «...Греческій языкъ съ Словенскимъ, по многимъ сходнымъ словамъ, также и по свойству склоняемыхъ именъ разными окончаніями, да и по преложенію частей изъ естественнаго порядка, во всякое произвольное сочиненія мъсто...» подобен (там же: 339 ).

Тредиаковский говорит о порче языка, многие прежние славянские «имена перешли черезъ столь многія уста, что всячески не могли они не повредиться» (там же: 347). Но он верит в бессмертие российского языка, ибо видит ему защиту: «Но Россійскій языкъ, есть единъ изъ Словенскихъ, да еще и цбйьнбйшій прочихъ, еслибъ его не портили; однако никогда и во вБки не повредятъ: щитъ ему и утвержденіе безсмертный нашъ языкъ церковный» (там же: 372 ).

Через скифский Тредиаковский возводит российский язык к языку потомков Иафета, сына Ноя, одного из родоначальников человечества и прародителя европейцев. 
Тредиаковский восторгается мощью и силой скифский племен: «Скитөія $<\ldots>$ въ самыи еще перьвыя времена приобрбла себъ славу. Аревнъйшіе жители въ сей пространной земль, не токмо не были никогда покорены чужой державб, но сами, какъ въ Европь, такъ наипаче въ Азіи, владбніе свое распространили сильно...» (там же: 325-326). Такая древность языка, заключает Тредиаковский, «полезнбе всему Россійскому народу» (там же: 341 ). Поскольку писатель ведет счисление российского языка от ветхозаветных времен, первенство он отдает словенскому языку «отъ слова или словесности», а его потомок - славенский язык - получил свое название от военной славы говорившего на нем народа (там же: 319).

\section{О ПОАИТИЧЕСКОЙ ЗАААЧЕ РУССКОЙ НАУКИ

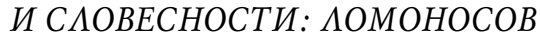

Помимо научной составляющей для $\Lambda$ омоносова была важна политическая задача изучения русской истории и словесности. Ученый утверждал идею древности славян, творя рационалистический миф: транслировал «научную информацию, обращенную к современному ему обществу, в мифопоэтической форме» (Абрамзон, 2005: 89). Иомоносов не считал скифов предками россиян, а напротив, указывал, что «...народ славенский был весьма храбрый, который преодолел мужественных скифов и с пространных селений выгнал, чего ему без великих сражений и знатных побед учинить нельзя было» (Иомоносов, 1952b: 21). Ему было близко происхождение самоназвания славянского племени от славных его деяний. В «Аревней Российской истории от начала российского народа до кончины Великого князя Ярослава Первого или до 1054 года», работу над первым томом которой он закончил в 1758 г., ученый пишет: «Признаки древнего имени славенского явствуют, во-первых, у Птоломея под названием ставан. Свойство греческого и латинского языка не позволяет, чтобы они выговорить могли славян имя. Ради того прежде ставанами, после склаванами и сфлаванами называли. Амазоны, или алазоны, славенский народ, по-гречески значат самохвалов; видно, что сие имя есть перевод славян, то есть славящихся, со славенского на греческий. Имена славенских государей, в одно время со славенским именем прославленных, не в самое то время могли принять начало, но перед тем задолго. По именам государей и героев своих народ прежде внутрь пределов назывался, потом славою дел утвердил себе славное имя, которое хотя поздно по свету распространилось, однако внутрь было давно в употреблении» (Иомоносов, 1952а: 182).

Аомоносов считал варягов потомками роксолан - славенского народа, жившего в междуречье Анепра и Аона и говорившего на славенском языке, «несколько от соединения со старыми германцами испорченным» (Иомоносов, 1952b: 22). Поэтому и в именах князей, пришедших от варягов, он видит русские корни: «Осколд речение есть славенское и значит обоюдный топор» (там же: 23). Ученый для доказательства ссылается на Псалом 73: «...секирою и оскордом (или осколдом) разрушиша.Аир происходит от слова деру, якобы драч. Ольга названа от облегчения матери своея рождением» (там же). Аомоносов вслед за Тредиаковским продолжил российский вектор спекулятивных этимологий, имевших не научное, а идеологическое значение.

Г. Ф. Миллер совершенно справедливо утверждал, что незначительного звукового сходства слов роксолане и россияне вовсе недостаточно для возведения российского народа и имени к данному этносу. Однако Аомоносов за неимением материальных артефактов для доказательства обратного привлек этимологию: «1) Перемена имени роксолане на россияне весьма невелика... Аитеру $\sigma$ переменяют иногда аттики на $\zeta$, то 
недивно, что из речения россолане сделалось у греков роболане, а слово россолане не больше разнится от россиане, как только окончанием по разности языков» (там же: 26). Ссылаясь на Плиния и Христофора Целлария, Аомоносов предполагает, что слово роксолане может быть составлено из названий россы и аланы. Из чего автор делает вывод, будто между реками Анепром и Аоном некогда существовало племя россов: «А как слово росс переменилось на русс или русь, то всяк ясно видит, кто знает, что поляки о в выговоре произносят нередко как у, напр. бог, буг; мой, муй; король, круль; ров, рув; конь, кунь; толстый, тлустый, и проч. Сие имя иностранные писатели девятого века и позже услышав от поляков, стали россов называть руссами. И сами россы называли себя тем именем долгое время оттого, что столица была сперва в полянех, славенском народе, то есть в Киеве, и великие князи российские нередко польских принцесс в супружестве имели» (там же).

Аомоносов утверждает, что множество племен (чехи, лехи, морава, поморцы, славяне, сербы, болгары, поляне, бужане, кривичи, древляне, белоозерцы, суждальцы и проч.) говорило на славенском языке еще до Рождества Христова. Греки и латины, пишет Аомоносов, называли их сарматами, и роксолане находились между ними. «И так понеже народ российский с народом роксоланским есть одного имени, одного места и одного языка... Ибо никоею мерою статься не может, чтобы великий и сильный народ роксоланский вдруг вовсе разрушился, а после бы на том же месте, того же имени и того же языка сильный же народ вдруг проявился, а не был бы с первым одного происхождения» (там же: 29). Аомоносов убежден, что славенский язык ни от греческого, ни от латинского не происходит, но на синхронном срезе он упоминает имя Августа - основателя Римской империи, носившего титул Отца Отечества. Иомоносову важно, что во времена могущества Римской империи на обширных пространствах Европы существовало не менее сильное объединение, могущие побивать и римлян.

\section{«СЫН ЯЗЫКА СКИФОВ»: СУМАРОКОВ}

Как и Тредиаковский, Сумароков называл скифский язык предком российского языка. «Объявивъ о происхожденїи нашего языка, - пишет автор статьи “О коренных словах русского языка”, - что онъ сынъ языка Скиөовъ въ древности мужествомъ преславнаго народа, которымъ въ прошедшемъ вђкђ безчисленная многонародїемъ Хина покорена...» (Сумароков, 1759: 95). Языковые примеры, как кажется Сумарокову, он черпает из одиннадцати скифских языков, типа: «Пьтухъ, на нбкоторыхъ Скиөскихъ языкахъ называется Курасъ, Куразъ, и Коразъ, безъ прембненїя пола сходственно со словомъ Курица» (там же: 94-95; курсив наш. - А. Р., Ю. С.). Можно отметить, что, обращаясь к примерам из «скифских» языков, Сумароков чутьем писателя улавливает именно те тематические группы, которые впоследствии были предложены основателем глоттохронологии американским лингвистом М. Сводешом как инструмент для оценки степени родства между различными языками по такому признаку, как схожесть наиболее устойчивого базового словаря. У Сумарокова это термины родства, названия явлений природы, растений. Весьма обширна тематическая группа названий животных и птиц: коза, утка, гусь, волк, медведь, агнец, кобыла, овиа, петух, курица; названий родства; домашней утвари. «Съ довольною вђроятностїю» Сумароков утверждает мотивацию слова Аюбить глаголом Бить (там же: 95). В некоторых скифских языках, пишет он, ребенок называется Бала, оттого и происходит русское Баловать (там же: 94). 
Используя межъязыковые совпадения, он объясняет название северного ветра Борей. Исходное слово Бур было мотивировано, по Сумарокову, суровостью его произношения. Этот признак лег и в основу названия конской шерсти. От слова Бур происходит скифское название снега Бурун, и применительно к другой непогоде - Буря. Эти слова мотивируют наименование сурового, быстрого и холодного полночного ветра Борей, совместившего все три первоначальных ощущения. А для жителей благорастворенной Греции, пишет Сумароков, холодный ветер, дувший от неких народов, стал мотивацией их этнического обозначения (там же: 100). Очевидно, речь идет о Гиперборее - в древнегреческой и наследующих мифологиях это легендарная северная страна, место обитания блаженного народа гипербореев.

Отметим, что более авторитетная в современной лингвистике ностратическая гипотеза в настоящее время дополняется теорией борейских языков (от Борея - северного ветра). Это гипотетическая макросемья языков еще более высокого уровня, чем ностратическая (основанием для гипотезы о существовании «борейского» единства являются некоторые совпадения в базисной лексике ностратической, сино-кавказской, америндской, аустрической макросемей).

\section{ВЫВОАЫ}

В основании «благорастворенного» мира лежат порядок и гармония. Фундаментом порядка является в большой степени язык: чем древнее язык, тем крепче фундамент нации. Авторы XVIII столетия ищут корни русского языка в глубокой древности в античных (дохристианских) и даже ветхозаветных временах. Не имея научных методов исторических и лингвистических реконструкций, Тредиаковский, Аомоносов, Сумароков зачастую прибегают к надуманным этимологиям. Но для российских авторов эти упражнения не были научными штудиями, а были попыткой собственной космогонии, сотворения нового мифа. Именно поэтому всем известная полемика трех «культурных героев» века Просвещения «свидетельствует не о принципиальных концептуальных расхождениях между ними, а о возможности частных отличий в интерпретации отдельных пуристических требований...» (Живов, 2007: 9).

У отечественных писателей и ученых XVIII в. псевдофилологические работы имели, в том числе, и политический характер. Их задача - обосновать претензии русской нации и русского языка на древность, величие и равноправие не только с современными народами и языками, но и с древними, сакральными. Русский язык, считают наши авторы, прямо указывает на древность русского народа. Сила нации для писателей и ученых XVIII в. связывается во многом с древностью языка, множественностью его этимологических связей, наличием коренных слов, семантическим богатством.

\section{ПРИМЕЧАНИЯ}

1 Подробный анализ этимологий Тредиаковского в алфавитной последовательности см.: Клубков, 2002.

2 Очевидно, Тредиаковский имеет в виду работы Шарля Роллена разных лет.

\section{СПИСОК АИТЕРАТУРЫ}

Абрамзон, Т. Е. (2005) Просветительский «миф творения» в «Письме о пользе стекла» М. В. Аомоносова // Вестн. Оренбург. гос. ун-та. № 1. С. 89-94.

Виролайнен, М. Н. (2007) Исторические метаморфозы русской словесности. СПб. : Амфора. $495 \mathrm{c}$. 
Живов, В. М. (2007) Язык и стиль А. П. Сумарокова // Русский язык в научном освещении. № 1 (13). C. 7-51.

Клубков, П. А. (2002) Этимологии Тредиаковского как факт истории лингвистики // Humanitāro zinātnu vāstnesis. № 2. C. 58-68.

Аомоносов, М. В. (1952а) Аревняя Российская история от начала российского народа до кончины Великого князя Ярослава Первого или до 1054 года // Аомоносов М. В. Полн. собр. соч. : в 11 т. М. ; $\Lambda$. : Изд-во АН СССР. Т. 6.690 с. С. 163-286.

Аомоносов, М. В. (1952b) Замечания на диссертацию Г.-Ф. Миллера «Происхождение имени

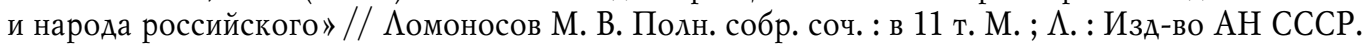
T. 6.690 с. С. $17-80$.

Погосян, Е. (1999) Русь и Россия в исторических сочинениях 1730-1780-х годов // РОССИЯ / RUSSIA. Вып. 3 (11): Культурные практики в идеологической перспективе. Россия, XVIII - начало ХХ века. М. : ОГИ. 278 с. С. 7-19.

Свирская, В. Р. (1952) Примечания. К работе 3 [Замечания на диссертацию Г.-Ф. Милхера «Происхождение имени и народа российского»]// Момоносов М. В. Полн. собр. соч. : в 11 т. М. ; $\Lambda$. : ИзА-во АН СССР. Т. 6.690 с. С. 546-559.

Сумароков, А. П. (1759) О коренныхъ словахъ Русскаго языка // Трудолюбивая пчела. Февраль. СПб. С. 91-101.

Тредиаковский, В. К. (1849) Три разсужденія о трехъ главнбйшихъ древностяхъ россійскихъ, а именно: І. О перьвенствъ словенскаго языка предъ тевтоническимъ. II. О первоначаліи Россовъ. III. O Варягахъ Руссахъ. Словенскаго званія, рода, и языка // Тредиаковский В. К. Соч. : в 3 т. СПб. : Смирдин, тип. воен.-учебн. завед. Т. 3.542 с. С. 319-540.

Аата поступления: 15.04.2015 2.

\author{
ON THE ORIGIN OF THE RUSSIAN NATION \\ AND THE RUSSIAN LANGUAGE: \\ LOMONOSOV, TREDIAKOVSKY, SUMAROKOV \\ A. V. RASTYAGAEV \\ (MOSCOW CITY PEDAGOGICAL UNIVERSITY (SAMARA BRANCH)), \\ YU. V. SLOZHENIKINA \\ (SAMARA STATE TECHNICAL UNIVERSITY)
}

The authors analyse the controversy of the origin of the Russian nation and the Russian language in 1757-1759. We look at the ideological parallels between the works that V. K. Trediakovsky, M. V. Lomonosov and A.P. Sumarokov wrote at that time: "Three Discourses on Three Most Important Russian Antiquities" (Trediakovsky, 1757), "The Ancient Russian History”, vol. 1 (Lomonosov, 1758), "On the Root Words of the Russian Language" (Sumarokov, 1759).

Trediakovsky considered the Russian language to have originated from Japheth's sons. The predecessor of the Russian language was the language of Scythians, who originally spoke Slavonian. This proto-name was linked both to the roots "word" and "fame". The chronology Trediakovsky developed implied the preserved purity of the Russian language, as well as its antiquity and power - indeed, a good ancestry for the Russian nation.

Lomonosov's accent was on the political aspect of Russian science, language and literature. Also accepting the idea of Slavs' glorious ancestry, Lomonosov nevertheless did not fit Scythians into the picture, citing Slavs' victories over them as the reason. He considered Varangians the descendants of the Roxolani - the Slavonian people who lived in the interfluve of the Dnieper and the Don and spoke Slavonian. Lomonosov asserted that the majority of tribes had spoken Slavonian as early as before the Nativity. Lomonosov was convinced that the Slavonian language did not stem from either Greek or Latin, but stood as their equal.

Like Trediakovsky, Sumarokov considered the language of Scythians to be the predecessor of the Russian language. The author admired the battle glory of the Scythian tribes. Sumarokov's article 
contains a large number of etymological comparisons. His authorial instinct helped him choose the historical wordgroups which also lie in the focus of contemporary comparative historical studies.

While disagreeing on matters of secondary importance, Trediakovsky, Lomonosov and Sumarokov stood united on the issue of unity between research and patriotic tasks of the Russian language. Russian research and criticism by the mid-18 th century had formulated a response to the Petrine reforms, which led to the specific cultural 'isolationism' of the new Russian nation.

Keywords: $18^{\text {th }}$ century, origin of the Russian nation, origin of the Russian language, V. K. Trediakovsky, M. V. Lomonosov, A. P. Sumarokov.

\section{REFERENCES}

Abramzon, T. E. (2005) Prosvetitel'skii «mif tvoreniia» v «Pis'me o pol'ze stekla M. V. Lo-monosova [An Enlightenment "Creation Myth" in Lomonosov's "Letter of the Benefits of Glass"]. Vestnik Orenburgskogo gosudarstvennogo universiteta, no. 1, pp. 89-94. (In Russ.).

Virolainen, M. N. (2007) Istoricheskie metamorfozy russkoi slovesnosti [Historical metamorphoses of Russian literature]. St. Petersburg, Amfora Publ. 495 p. (In Russ.).

Zhivov, V. M. (2007) Iazyk i stil' A. P. Sumarokova [Language and style of A. P. Sumarokov]. Russkii iazyk v naucbnom osveshchenii, no. 1 (13), pp. 7-51. (In Russ.).

Klubkov, P. A. (2002) Etimologii Trediakovskogo kak fakt istorii lingvistiki [Trediakovsky's etymologies as a piece of history of linguistics]. Humanitāro zinātnu vāstnesis, no. 2, pp. 58-68. (In Russ.).

Lomonosov, M. V. (1952a) Drevniaia Rossiiskaia istoria ot nachala rossiiskogo naroda do konchiny Velikogo kniazia Iaroslava Pervogo ili do 1054 goda [The ancient Russian history from the beginning of the Russian people to the death of the Grand Prince Yaroslav the First or until 1054]. In: Lomonosov, M. V. Polnoe sobranie sochinenii [Complete works]. Mos-cow ; Leningrad, Publ. House of the Academy of Sciences of the USSR. Vol. 6. Pp. 163-286. (In Russ.).

Lomonosov, M. V. (1952b) Zamechaniia na dissertatsiiu G.-F. Millera «Proiskhozhdenie imeni i naroda rossiiskogo" [Notes on G.-F. Miller's thesis "The Origin of the Name and Nation of Russians"]. In: Lomonosov, M. V. Polnoe sobranie socbinenii [Complete works]. Moscow ; Leningrad, Publ. House of the Academy of Sciences of the USSR. Vol. 6. Pp. 17-80. (In Russ.).

Pogosian, E. (1999) Rus' i Rossiia v istoricheskikh sochineniiakh 1730-1780-kh godov [Rus' and Russia in historical writings of the 1730s-1780s]. In: ROSSIIA / RUSSIA. Issue 3 (11): Kul'turnye praktiki videologicheskoi perspektive. Rossiia, XVIII - nachalo XX veka [Cul-tural practices in the ideological perspective. Russia, the $18^{\text {th }}$ - early $20^{\text {th }}$ century]. Mos-cow, OGI Publ. 278 p. Pp. 7-19. (In Russ.).

Svirskaia, V. R. (1952) Primechaniia. K rabote 3 (Zamechaniia na dissertatsiiu G.-F. Millera «Proiskhozhdenie imeni i naroda rossiiskogo») [Notes to Paper 3 (Notes on G.-F. Miller's thesis “The Origin of the Name and Nation of Russians")]. In: Lomonosov, M. V. Polnoe sobranie socbinenii [Complete works]. Moscow ; Leningrad, Publ. House of the Academy of Sciences of the USSR. Vol. 6. 690 p. Pp. 546-559. (In Russ.).

Sumarokov, A. P. (1759) O korennykh" slovakh" Russkago iazyka [On the root words of the Russian language]. Trudoliubivaia pchela. February. St. Petersburg. Pp. 91-101. (In Russ.).

Trediakovsky, V. K. (1849) Tri razsuzhdeniia o trekh" glavnðishikh» drevnostiakh» rossiiskikh", a imenno: I. O per'venstvъ slovenskago iazyka pred" tevtonicheskim". II. O pervonachalii Rossov". III. O Variagakh" Russakh». Slovenskago zvaniia, roda, i iazyka [Three discourses on three most important Russian antiquities, viz.: I. On the anteriority of the Slovenian language to the Teutonic language. II. On the primacy of the Ross people. III. On the Russian Varangians of Slovenian origin, race and language]. In: Trediakovsky, V. K. Sochineniia [Works]: in 3 vols. St. Petersburg, Smirdin's Publ. Vol. 3. 542 p. Pp. 319-540. (In Russ.).

Submisson date: 15.04.2015.

Растягаев Андрей Викторович - доктор филологических наук, заведующий кафедрой филологии и массовых коммуникаций Самарского филиала Московского городского педагоги- 
ческого университета. Адрес: 443081, Россия, г. Самара, ул. Стара-Загора, д. 76. Тел.: +7 (846) 205-76-45. Эл. адрес: avr67@yandex.ru

SPIN-код РИНЦ: 8717-1760.

Сложеникина Юлия Владимировна - доктор филологических наук, профессор Самарского государственного технического университета. Адрес: 443100, Россия, г. Самара, ул. Молодогвардейская, 244. Тел.: +7 (846) 278-43-11. Эл. адрес: goldword@mail.ru

SPIN-код РИНЦ: 5293-4241.

Rastyagaev Andrei Viktorovich, Doctor of Philology, Chair, Department of Philology and Mass Communications, Moscow City Pedagogical University (Samara branch). Postal address: 76 StaraZagora St., 443081 Samara, Russian Federation. Tel.: +7 (846) 205-76-45. E-mail: avr67@yandex.ru

Slozhenikina Yulia Vladimirovna, Doctor of Philology, Professor, Samara State Technical University. Address: 244 Molodogvardeyskaya St., 443100 Samara, Russian Federation. Tel.: +7 (846) 278-43-11. E-mail: goldword@mail.ru 